\title{
15. A Cyberconflict Analysis of Chinese Dissidents Focusing on Civil Society, Mass Incidents and Labour Resistance
}

Athina Karatzogianni and Andy Robinson

\section{Introduction}

This chapter employs the cyberconflict perspective (Karatzogianni, 2006; 2009; 10 March 2010; 2012a; 2012b; Karatzogianni and Robinson, 2010) to offer an in-depth analysis of Chinese dissidents in the People's Republic of China (PRC) focusing particularly on the last decade. A distinction is drawn between sociopolitical (or active) social movement uses of the Internet — which focus on organization, mobilization and the networked form of the medium itself — and ethno-religious (or reactive) social movement uses, which subordinate the medium to vertical logics. These are often expressed in terms of ad hoc mobilizations and tit-for-tat defacements and cyberattacks adhering to closed and fixed identities, such as nationality, religion and ethnicity.

Cyberconflict is a synthesis of three overlapping theories of social movement theory (for sociopolitical movements), conflict theory (for ethnoreligious movements) and media theory (the intersection of cyberconflict, capitalism, and the state). This theory is applied in the context of a systemic structural analysis of capitalist power, in a context in which neoliberalism and regime maintenance are both mutually reproducing and undermining. While the Internet, as a networked technology, is most appropriate for networked forms of power, it exists in a dynamic field in which hierarchies, and hierarchy-network hybrids, also proliferate, containing and 
channeling its emancipatory potential through strategies of recuperation, repression, inclusion and exclusion. More specifically, cyberconflict theory examines how politico-economic reforms, the media environment, and e-governance have affected dissent in China (i.e. communist party ideology, constructions of social and political identities, representations of and by dissidents, and link to e-governance; control of information, level of censorship; alternative sources; media effects on policy; political contest). Second cluster of elements of concern are the effect of ICTs on mobilization structures, organizational forms, participation, recruitment, tactics and goals of dissidents, as well as changes in framing processes and the impact of the political opportunity structure on resistances in China. Third, in relation to ethnic, religious and cultural dissent, examines how the communist party state and dissident group identities are constructed in relation to ethnic/religious/cultural difference, and the national and competing identities construction. Also, hacktivism (or invariably termed digital activism, tech activism, cyberactivism) and information warfare in China are discussed in a variety of settings, especially in relation to social networking media and contemporary dissent.

To engage with these areas, this chapter is divided into three main sections. The first discusses the political environment in China to provide the context for dissent and involves a broad stroke on neoliberalism in China with a further discussion on censorship and control in this environment. A second section maps networked dissent in terms of the impact and use of Information Communication Technologies (ICTs) in relation to civil society, mass incidents and labour resistance, and shows how it links to broader resistance in the global mediascape. The final section concentrates on nationalism and the symptomatic repression of ethnic and religious minorities, as well as nationalism, which fuels and links to cybercrime and patriotic hacking. 


\section{Hypercapitalism and its Discontents}

Critics such as He Qinglian have suggested that neoliberalism in China has led to growing inequality and corruption (Arrighi, 2007: 15-16). In effect, the transnationally-led growth strategy has transferred resources en masse to private capital in coastal cities, so as to provide incentives to lure transnational capital (Wei and Leung, 2005; Yusuf and Wu, 2002), an approach known in China as 'building nests to attract birds' (Zweig, 2002: 60). Changes in the urban landscape, for example, show the replacement of corporatist and traditional spaces with spaces of information-economy capitalism (Fu, 2002: 114). Transnational capital dominates urban areas both symbolically and economically, expressing itself in orthogonal growth (Gaubatz, 1999). The arrangement of spaces along a functional capitalist level, with clustering of economic functions, is particularly apparent (Rimmer, 2002). Finance capital and landlords, aided by technocratic political leaders, become dominant classes within local power-structures (Jessop and Sum, 2000: 2288; Yusuf and $\mathrm{Wu}, 2002$ : 1224; Chen, 1998). Transnational capitalist projects are unrestricted by state power $(\mathrm{Wu}, 2000: 1363)$. The state is able to extract rents on transnational flows (Zweig, 2002: 23-24), but suffers from increased dependency, as well as from the growing power of those on whom it depends to resist rent-extraction. As in all global cities, local elites maintain rent-extraction mainly through immobile infrastructure such as real-estate (Brenner, 1998: 15), which function as the source of monopolistic superprofit nexuses, allowing the extraction of above-market profits through non-reproducible conditions (Taylor, 2000). In China, such rent-extraction runs against traditional rights of state tenants, who local elites dispossess at will in order to accumulate revenue from corporate rents (Zhou and Logan, 2002: 141). 
Furthermore, there is a discontinuity in global city emergence, with connectivity but not command-and-control functions (i.e. maintaining authority but with a distributive style of decision making), spreading to peripheral locations. Beijing for instance has much higher quantitative scores for connectivity than command-and-control (Taylor et al., 2009: 231, 238), while Hong Kong scores third in the world for connectivity, but lacks global command functions (Taylor et al., 2009: 234, 237-238). Chinese global cities, as with others in the global South, differ from their Northern counterparts in being focused on attracting foreign investment (Wei and Leung, 2005: 19-20; Shi and Hamnett, 2002: 128). It can thus be argued that (coastal urban) China has become a dependent peripheral state within neoliberal capitalism, rather than an emergent hegemonic contender. This regime of accumulation is partly sustained in classic Southern fashion (Wolpe, 1972) by the persistence of a largely non- or semi-capitalist agrarian sector, which underpins sub-reproduction-cost wages and resultant comparative advantage. This dual economy allows the hyperexploitation of undocumented migrants from rural to urban areas, with rural areas effectively treated as an internal periphery. Like other such models, it is destabilised by its simultaneous reliance on, and accumulation-by-dispossession at the expense of, the non- or semicapitalist sectors. In addition, cities continue to rely on rural hinterlands (Lin, 2002: 302).

Some scholars write of a crisis of governance, with the regime seeing the effects of neoliberalism as introducing instability that threatens to produce 'chaos' (luan) (Kluver, 2005: 78). Along with other means such as nationalism, e-governance initiatives have been introduced as an attempt to re-stabilise Chinese society. Part of the difficulty with the position of the Internet in China is that it is simultaneously 
useful for neoliberalism and harmful to authoritarianism (hence to the specific form of neoliberalism prevalent in China). Rawnsley (2007) argues that the Internet's horizontal, networked structure is appropriate to 'economic modernisation', and hence necessary for China, but clashes sharply with a centralised, hierarchical governance system. Regime integration depends on mainly vertical structures. Hence, Qiu (2003: 10-11) suggests that the path-dependency of institutional legacies is the main reason for Internet censorship. However, there are also real dangers. The regime is highly fearful of 'linking-up' (chuanlian), the formation of horizontal connections and solidarities between different sites, which was central to the Cultural Revolution and is seen as prefiguring society-wide mobilisation. The widely observed result is a selfcontradictory relationship in which China both embraces the Internet and fears and seeks to control it (Taubman, 1998; Qiu, 2004: 101; Kalathil and Boas, 2003; Endeshaw, 2004).

Less widely noted is the basis of this contradictory policy in divisions between fractions of the Chinese elite, with growth-oriented technocrats pitted against statecontrol interests in the army, propaganda system, and security agencies. The former care more about developmental-state concerns, the latter about keeping power and winning any emerging cyberwars (Qiu, 2004: 110). The latter institute policies which are unjustifiably costly in developmentalist or neoliberal economic terms, but which also serve as job-creation and import-substitution initiatives inside China (ibid., 112). China's attitude to global information flows is thus self-contradictory. The regime both wishes for such flows for economic reasons, and fears that they could be its downfall (Bennett, 2010). In particular, the regime is afraid of pro-democracy messages coming out of the global mediascape (Appadurai, 1990: 305). 
Moreover, it has been noted that ' $[\mathrm{t}]$ he Chinese government has chosen to address through information technology, problems of corruption, transparency and local government reform, and the development of poor areas' (Kalathil and Boas, 2003: 13). In effect, a controlled Internet provides the possibility for feedback mechanisms, which fall short of accountability, and therefore fall within the regime's view of stability. In part, this is an attempt to combat the culture of dissimulation by allowing a direct connection between the centre and individual citizens, bypassing local officials and allowing their surveillance by the centre (Kluver, 2005: 85). These are a recent, computer-mediated variance of a wider reliance on 'limited bottom-up citizen participation' as an accountability mechanism to control local officials, a practice which is dangerous for the regime, as participants often take up politicised issues (Minzer, 2009: 82-83). Such mobilisation is aided by the fact that many local governments have been slow to take up computer technologies (Qiu, 2004: 107; Tong and Lei, 2010).

Further, the regime is making increasingly sophisticated use of control modalities which combine commercialisation with government restriction, co-opting private actors to reinforce control. This process is creating a type of Internet openness, which is restricted to entertainment functions (Weber and Lu, 2007; Qiu, 2004: 113-114). Despite the apparent softening, repression is never far below the surface, and seems to be constructed to pre-empt and premediate dissent in advance through the logistical closure of space and the multiplication of both formal and informal regulations. For instance, in November 2012, the Communist Party congress was accompanied by at least 130 arrests of dissidents, others placed under house arrest or exiled from Beijing, bans on pigeons, balloons, taxi door handles, ping-pong balls, and remote-control aircraftrestrictions on transport, and closures of NGOs such as the Beijing Aizhixing 
Institute of Health Education, which offers advice to migrant workers. At least half the sex workers in the city were reportedly arrested and expelled from Beijing. The Ministry of Information Technology expressed the need to 'seal the network' (fengwang), during the Party Congress, and it was impossible to access the New York Times article exposing the financial operations of Premier Wen Jiabao (Barboza, 26 October 2012; Jacobs, 3 November 2012). 'Unlucky' words such as 'death', 'die' and ‘down' were even banned from TV shows (Economic Times, 3 November 2012).

This general climate of repression — which is typical of major events in China creates a generalised feeling of disempowerment, an inability to protest, and even an existential gap between the regime and any possible opposition. The Economic Times (3 November 2012) quotes a microblogger: 'In the face of these absurdities, we are powerless. It's a reminder that no matter how ridiculous and comical, this is an era that we can't laugh in.' Ai Weiwei, an international artist and famous dissident, who is going to be discussed more extensively below, said his police minders allowed him to engage with anything, except the coming party congress. 'To be honest, it's O.K. because it's just an internal meeting for those people. It has nothing to do with me. Or with anyone else, really' (Jacobs, 1 November 2012b). Shao Jiang (1 November 2012), another leading dissident summarizes in one paragraph the political climate in the country: 'Stability maintenance' has been bolstered as a way to strip the rights of human rights lawyers, activists, petitioners and digital activists. This is a departure from the reign of President Jiang in the 1990s, which was characterized by its suppression of members of the China Democracy Party and Falun Gong practitioners. Methods of suppression under the recent administration have become more calculating than before, with authorities making blatant and extensive use of diverse and often harsher techniques to retaliate against activists, including abduction, enforced 
disappearance, torture, illegal detention in 'black jails', soft detention, forced 'tourism' (a form of residential surveillance away from home), and trumped-up charges like 'disrupting public order' or 'tax evasion'.

Such intimidation is focused on activists, and its degree of visibility to the wider public is debatable. The regime relies on an array of 'deliberately vague and arbitrary regulations' to maintain control (Rawnsley, 2007; c.f. Dickie, 2007). In this context, signals such as web censorship and news bias may serve to signal the limits to tolerated dissent at a particular time. Tuinstra (2009) suggests that Chinese users now rely on the Internet as their eyes and ears regarding government policy and practice, creating risks to the government in interfering too much with it. Pye (2001) suggests that Chinese leaders rely on informal decision-making to maintain control. This echoes broader patterns of 'shadow power' typical of the global South.

China's cyberspace censorship regime has been deemed the most extensive in the world (see Walton, 2001; Chase and Mulvenon, 2002; Qiu, 2004; Dowell, 2006; Lum, 2006; Karatzogianni, 2006; Minzer, 2009; McKinnon, 2010; Zittrain and Palfrey, 2010; Cunningham and Wasserstrom, 2011). China seeks to control the Internet by funneling connections 'through a small number of state-controlled backbone networks', which are in principle vulnerable to censorship and surveillance (Kalathil and Boas, 2003: 21). This is an attempt to combat the horizontal, rhizomatic architecture of the Internet. It is continuous with the Maoist ideal of vertical control of communication (ibid. 18).

Nevertheless, the viability of such strategies long-term and on a wider scale is questionable in the current global communications environment. This has led to an 
emerging policy of 'not trying to control too much' (Dickie, 2007). It has been suggested that China is using its censorship systems 'sparingly since this prevents a new generation of Internet users from discovering the numerous ways netizens have figured out to thwart their efforts' (Tuinstra, 2009), in effect choosing a relatively lightly censored Internet over a more heavily censored, and therefore more widely resisted, control system. It has also been suggested that the 'great firewall' has been replaced or supplemented with second- and third-generation forms of control based on corporate censorship, the normalisation of surveillance, and state-sponsored information campaigns (MacKinnon, 2010: 27). This makes the approach of simply enabling dissidents to circumvent first-generation blocking insufficient or even dangerous (ibid. 30). As a result of such measures, Yang (2009) argues that China has moved from sovereign power based on 'hard control' such as Internet censorship, towards disciplinary and biopolitical power based on 'soft control' through using human actors' self-censorship and responsiveness to cues.

On the other hand, the feeling of efficacy inspires online protests. Surveys also reveal that people both trust the Internet as a source of information, and feel it to be an open space in which their discussions are not restricted (Yang, 2009: 132). Tuinstra (2009) suggests that the Internet obtains trust as an information source in China because western media are suspected of anti-Chinese bias, and Chinese media regarded as controlled. Information continues to reach Chinese Internet users through social media and other sources, leading to a credibility gap, which delegitimates the government (Rawnsley, 2007). However, skepticism is necessary regarding the effects of information flows. Quantitative research suggests that the credibility of official media is a much bigger correlate of political outlook than access to alternative information (Hu and Zhou, 2002). Similarly, Thornton (2009: 202-203) suggests that problems of 
astroturfing and difficulties assessing the scale of dissent render it difficult for online movements to gain trust. The regime is also trying to steer online discussions through the use of paid astroturfers, known in China as the 'fifty cent party'. It has been estimated that at least 280,000 astroturfers are paid by the Chinese regime, in addition to party members who do it for free, and independent bloggers co-opted by regime patronage (Bandurski, 2010; MacKinnon, 2010: 23-24). There is also a system of hiring college students to work part-time as Internet police and censors (Qiu, 2003: $11)$.

\section{Transnational Digital Networks of Dissident and Protest}

'The struggle is worthwhile, if it provides new ways to communicate with people and society'.

'If someone is not free, I am not free'.

- Ai Weiwei

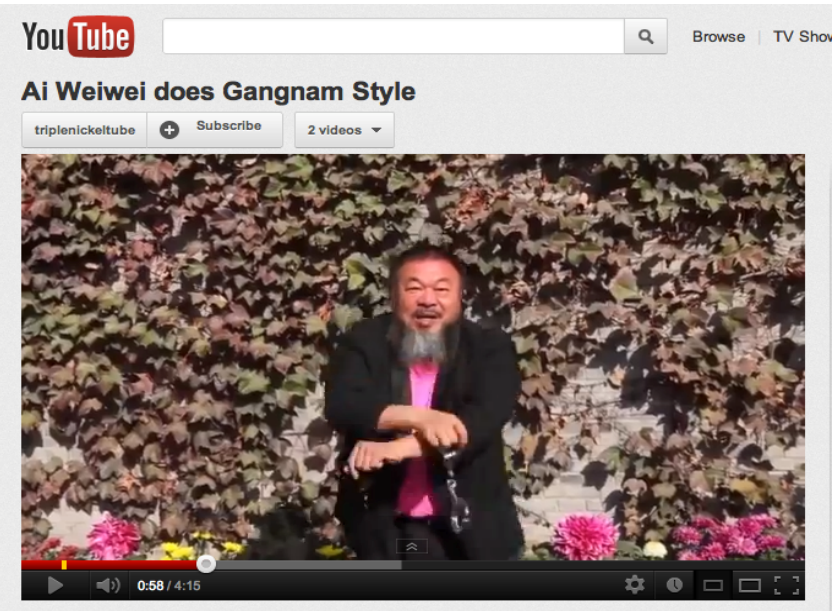




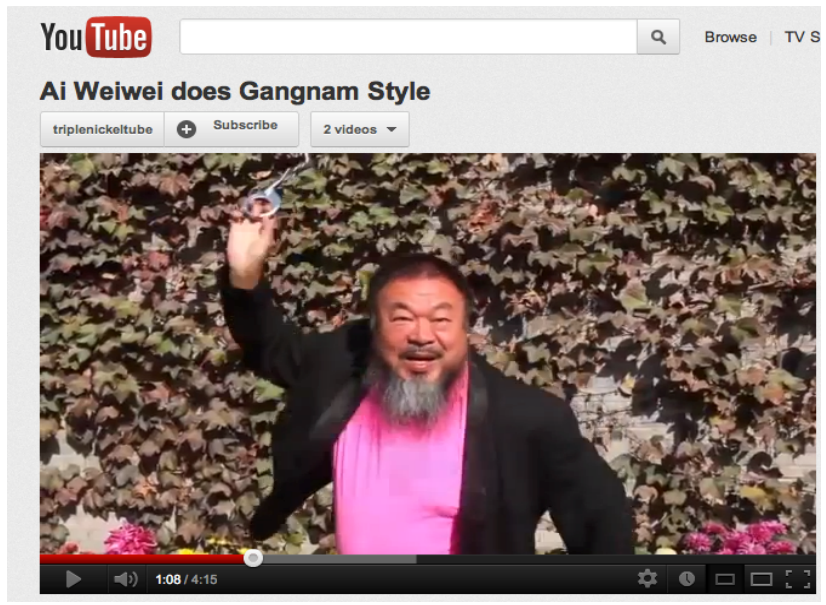

(Image 1 and 2. Screenshots of artist and dissident Ai Weiwei's parody of PSY's Gangham style on YouTube incorporating handcuffs in his dance routine.)

'Overall we feel that every person has a right to express themselves and this right of expression is fundamentally linked to our happiness and even our existence. When a society constantly demands that everyone should abandon this right, then the society becomes a society without creativity. It can never become a happy society'.

- Ai Weiwei video interview Lamborn, 25 October 2012 
(Image 3. Twitter Screenshot: Debating Chinese dissidents and Western Values on Twitter, 30 July 2012)

The above images and words which commenced this section show the global media literacy of celebrity dissident Ai Weiwei, which extends to the appropriation of the popular 'Gangnam Style' Internet meme. This suggests that $\mathrm{Ai}$ is an artist and dissident who understands social media activism and knows how to obtain and retain the attention of a global audience. Ai Weiwei here shows himself to be more attuned to the global mediascape than the Chinese regime, which persists in its skepticism towards cyberspace and global media culture. It is thus not entirely inaccurate to say that Ai has 'escaped' through YouTube: he is able to exist within an alternative sociopolitical community through a computer-mediated transition to a global scale.

This type of dissident is partly a product of immaterial labour development in China. Intellectuals and artists, involved in what has been termed immaterial affective labour (Hardt and Negri, 2000; Karatzogianni and Schandorf, 20 October 2012), are often expected to be dissidents, and the correlation of dissent and intellectual status are expressed in artistic and literary awards to Chinese dissidents. This expectation of dissent is transmitted from the west via global discourse, and runs against a Chinese tradition expecting intellectuals to serve the state. Intellectuals in China move within a space in which limits to government tolerance constantly shift. China also has a division between Tizhi (official system) writers and Minjian (literally 'among the people', i.e. unofficial) authors. Minjian intellectuals often admit to being outsiders, but deny being dissidents or activists as they seek to stay just inside the margins of 
regime tolerance (Zhou, 2005). The Chinese regime is enthusiastic about international recognition of intellectuals, but unhappy when they use their status to demand reforms. For instance, when Mo Yan won a Nobel Prize for Literature, Chinese Communist Party $(\mathrm{CCP})$ propagandist Li Changchun observed that it 'reflects the prosperity and progress of Chinese literature, as well as the increasing influence of China' (Tatlow, 2012b), ignoring Mo's call for the release of Liu Xiaobo, a previous prize winner from 2010. Similarly, when Liao Yiwu won the German Book Trade's Peace Prize, he accepted his award with 'a scorching speech whose theme was: 'This empire must break apart' (Tatlow, 2012b).

The style of transnational dissent discussed here, resonates with broader cases of scale-jumping as a means to appeal to the global community to protect human rights. Wanning Sun (2010: 540) explains the usefulness for the scale-jumping concept:

Chinese media within the context of two related social processes: a growing social-spatial stratification within China on the one hand, and the formation of widespread but uneven translocal linkages on the other. Additionally, it may help us gain a clearer appreciation of how communication technologies and media practices either assist or inhibit the activity of scale-fixing or scalejumping, activities that are engaged in by various players: the state, capital, individuals, and of course, media institutions.

In other cases, such a rescaling has given considerable power to local actors whose political opportunities are blocked at a national level, through appeals using global human rights discourse (Sikkink, 1993). The Internet encourages such scale-jumping. As Severo et al. (2011), following Barabasi, have argued, an Internet posting moves 
an issue from a local to a global scale. This is partially the case in China, as the regime is unable to control hacktivist groups located outside China (Qiu, 2004: 113). This allows dissident groups to promote what Thornton (2009: 187-188) calls a 'boomerang' effect, with activism curving around local repression and indifference to generate foreign pressure on local elites. For instance, Ai Weiwei stands out as particularly able to use the global mediascape, firstly in his use of social media to solicit funds, and secondly in conforming to the model of 'explicit' dissident which the western press understands. He uses this media-constructed role to engage with an international audience. Ai has also attempted to articulate transnational dissident concerns with wider social unrest in China. In particular, he has taken part in campaigns over the government's handling of the 2008 Sichuan earthquake in which 90,000 people died.

Despite this repression Ai, like many Chinese dissidents, stops short of a democratisation agenda, instead calling for liberalisation. In this, he is in continuity with many Minjian intellectuals. However, he is too explicit to be Minjian, and is rather the style of dissident that the west understands and appreciates as he is explicit and connected at the international level via social media and artist circles in major cities around the globe. For example his art is exhibited internationally and a movie made about his activism was played in many international film festivals. Kelliher (1993: 380) has argued that to understand what was termed 'the democracy movement' (minzhu yundong or shortened as minyun) in its various phases (19871989, 1986-1987 and 1989) means to 'examine how Chinese intellectuals conceived of democracy; what political role... assigned for themselves; and what sort of elitemass relations prevailed within the movement, between intellectuals, on the one hand, and workers and peasants, on the other'. In his analysis, Kelliher argues that 
mainstream activists who dominated the movement focused on liberalisation, as in the establishment of rights to protect people's freedoms from government interference. It was only radical elements of the movement who pushed for democratisation and popular sovereignty. The exile journal China Spring talked of 'first strike for human rights and then for democracy'. It is worth diverting here to add that one of the major articulators of Chinese dissidence are political exiles and the diaspora in western countries, Hong Kong, Macao, and Taiwan (for instance see M.Y.T. Rawnsley, 2012).

Yet it is the historical context which can provide the answer to the up until now failure of protest, dissidents and resistance groups to topple the 'Communist' regime, effectuate reform or engage in any sort of dialogue with the elites forming the hierarchies of the state apparatuses. When an opportunity seemed to present itself in the aftermath of the Arab Spring in 2011, dissident calls for mobilisation seemed to meet with little popular response. This failure to construct an overarching, popular dissident project is partly a result of the authoritarian practices routinised in contemporary China, from Internet surveillance to detention in labour camps to the everyday presence of street wardens and police. Another partial explanation is provided in the assertion by Kelliher (1993) that one of the reasons has been dissidents' demand of liberalization, instead of democratisation.

However, there are also problems in that the multitude, a thousand plateaus of dissent and rebellion — celebrity dissent, rural and labour unrest, and separatism — remains unarticulated under a common frame. This pushes dissent back into the arms of the regime. The Kelliher argument is significant also in another sense. Intellectuals monopolised the debate, creating an idea that excluded mass supporters and were unable to talk to peasants and workers in a language they understood, while the urban- 
rural divide devastated prospects for a mass democratic movement (Kelliher, 1993:

381). This democracy was limited in a sense to intellectuals to the extent that Kelliher argues that 'the notion of elite democracy was a close cousin to the new authoritarianism (xin quanweizhuyi) — the hard government/soft economy variety, the notion that democracy would have to wait until the economy developed (ibid., 381).

Within China, moves towards contestation on the up-down axis can be seen in terms of the still more cautious emergence of a networked civil society. Guobin Yang's voluminous work in particular makes a strong case that the Internet is driving an emerging civil society or public sphere in China. Within China, tolerated civil society groups have emerged synergistically with the Internet, facilitating participation (Yang, 2003: 405). For example, the emergence of environmental NGOs 'coincided with the development of the internet in China' (Yang, 2005: 58). Yang goes as far as to suggest that China is undergoing 'a veritable associational revolution' fuelled by the Internet (Yang, 2009). The incipient, dynamic nature of local civil society has rendered it particularly prone to adopt online methods (Yang, 2003: 406-407), with social uses emerging earlier than e-commerce and e-government (ibid., 411).

Guiheux (2009: 135-136) suggests that the Internet has contributed to an increase in the number and range of political voices in China. The emergence of Chinese civil society, effectively an included stratum in negotiation with market and state, is still severely constrained by the context, though this has not prevented it from negotiating the relationship (Yang, 2005: 66). In a study of online forum postings, Hang (2003) concludes that the Internet is creating a nascent virtual public space in China. Similarly, Reese and Dai (2009) observe that censorship now takes place against a 
background of global connectivity, with bloggers emerging as a media watchdog criticising censorship.

The 2009 Panyu anti-incinerator protest in Guangdong, Zhao (2011) shows the importance of modern technologies in generating pressure for protesters' aims. Suggesting that this is linked to the middle-class, upwardly-mobile constituency of the protests, Zhou argues that the Internet was used to get around regime censorship. Methods such as blocking websites, censoring newspapers, and interfering with protesters' transport arrangements proved insufficient given protesters are constantly evolving their use of ICTs. In addition, protesters were using modern technologies to disseminate live information, research and present alternative information, debunk government claims, and deter repression by filming officials (ibid. 20). New technologies create a means to challenge regime framing in such a way that the 'rightfulness' of protest can be articulated. She also draws attention to the postrepresentational nature of the protest, in which, when told to select representatives for negotiation, the crowd chanted: 'We don't want to be represented' (ibid. 17). However, protest leaders seem in practice to have tried to keep the movement within non-transgressive bounds (ibid. 23). The Internet is crucial in allowing such environmental movements to succeed. Ma Yan, an environmentalist who won the Goldman prize, pointed to social media as being responsible for the frequency of environmental protests in China: 'Social media is a game changer. People can educate themselves and share information' (Larson, 29 October 2012).

A recent example of how social media accelerate protest is the protest against the building of a petrochemical plant in Ningbo. According to news reports, the protest by mainly middle-class residents, organised through microblogging, smartphone apps and 
social media, was successful in forcing the authorities to cancel the project within two days (Larson, 29 October 2012). A similar case occurred in 2007, when residents in Xiamen used the Internet and text messaging to coordinate a demonstration against the building of a chemical plant (Yang, 2009: 129). Another such protest — which succeeded without much government opposition — was directed against the extension of a train line, which would reduce house values and pose a health risk (Cunningham and Wasserstrom, 2011: 17). The middle-class composition of the protest perhaps explains the widespread use of social media, but this protest also prefigures possible future mobilisations as the Internet spreads to working-class and rural populations. It seems likely that the Chinese regime will have increasing difficulty in its strategy of using information blocks to impede social movements.

Another successful example (there are obviously protests that do not and more research could be done into understanding impact factors), mainly involving students, another group of relative 'Internet haves', saw online protests rapidly diffuse around a murder at Beijing University in 2000. Protests on campus and online were closely coordinated, and the issue rapidly spread from the murder itself to issues of free speech online (Yang, 2003a: 469-472). Yang concludes that 'the internet facilitates if not completely satisfies the key conditions of the emergence of popular protest', overcoming information problems and offering speedy, low-risk means of communication (Yang, 2003: 472). Research on participants in pro-democracy protests in Hong Kong similarly suggest that the Internet was an important mobilising channel, with 54 percent listing the Internet or emails as important factors motivating them to join a march (Ma, 2009: 59). Protest organiser Ng Gene-bond first discerned widespread student concern about the 'Article 23' reform from web forums, then set up a website to promote the march (Ma, 2009: 58). Kuah-Pearce (2009: 112) terms 
this part of the emergence of a 'protest ideology' and 'protest space' in Hong Kong, with anti-globalisation overtones. Another recent example of this was the Occupy camp in Hong Kong, which ironically was tolerated while sites in America and Europe were suppressed. The camp lasted nearly a year before finally being suppressed, making it the last major Occupy camp to survive (Bradsher, 2010).

\section{'Mass Incidents' and Labor Resistance}

One recent phenomenon is the 'large-scale internet mass incident', which is a form of online protest usually used to censure government failures and corruption. The government has been forced to react quickly to such campaigns, and 'rush solutions to appease public opinion', as well as to channel them into e-government (Tong and Lei, 2010: i-ii). The mass unrest phenomenon in China is difficult to quantify as most incidents are unreported. According to official sources, there are around 80,000 'mass incidents' each year. The term 'mass incident' is regime-speak for a demonstration or revolt in which police repression or negotiation is attempted. Some of these cases involve 'serious clashes between the public and the police' (Li, 2008). Such incidents have increased sharply, from 8,700 per year in 1993 to 23,500 in 1999, 58,000 in 2003 (Keidel, 2005: 1), 80,000 in 2007, and 180,000 in 2010 (The Atlantic, 2012). China has apparently changed recording criteria since then to avoid further such publicity (Goldkorn, 6 January 2013). Commentators refer to the 'extraordinary scale of social unrest' shown by such clashes (Keidel, 2005: 1). The majority of incidents are almost certainly rural, with many focused on issues of land grabs, corruption, abuse by officials or police, or pollution. 
Reflecting Internet use patterns, these campaigns tend to express the political orientations of the middle-class and students, but these concerns can also focus on the mistreatment of vulnerable people by the elite. Indeed, according to Yang, the three main issues of online campaigns are nationalism, misconduct by the powerful, and harm to vulnerable individuals (Yang, 2009: 127, 129). The trick with such mobilisations is to catch the attention and imagination of the mass of Internet users who are mostly online for entertainment purposes. 'The more outrageous the incident, the more likely it is to arouse the virtual crowd' (Yang, 2009: 134).

Responding actively to the space opened by tolerance of localised protests, 'Internet mass incidents' have encouraged scrutiny at a local level. Local officials are put under mass surveillance for slips of the tongue, corruption and so on (Tong and Lei, 2010: 5-6). Other campaigns target police abuse. Like street protests, it has been suggested that online protests of this kind serve as a means to vent frustration against wider problems (Tong and Lei, 2010: 10) and that they are at root about 'the dark side of economic transformation' (Yang, 2009: 130).

The modalities of such protests have been hotly debated. In terms taken from new social movement theorists Poster and Melucci, Yang (2009: 129) argues that such campaigns are 'symbolic challenges'. Their main significance is in allowing the public to reframe issues. In contrast, Minzer (2009: 105) argues that, in a system where performance targets matter more than formal laws or legal rights, 'disgruntled parties' have learnt that Internet campaigns and mass petitions or protests (which put local leaders in violation of targets) are more effective than formal processes. The success of such protests shows both the regime's fear of widespread dissent and its 
preparedness to make partial concessions to head it off. In a cautionary analysis, Zheng (2008) warns that the most effective campaigns have been those that do not challenge the regime itself, instead dividing different factions of the regime against each other. When regime legitimacy is at stake, a repressive response it still typical. Activism is thus typically complicit with the regime's use of the Internet as a regime feedback mechanism (2008: 165). Conceding on such issues can be a way to prolong CCP rule without enacting substantive reforms (MacKinnon, 2010: 11). Furthermore, $\mathrm{Xi}$ Chen argues that, while petitioners have become more effective and achieved 'impressive successes' using the Internet, regime censorship has made this channel inaccessible in many cases (2009: 456). The mechanism of scale-jumping is also central to such protests, which often target local issues or problems, but bypass local power blockages by operating on a national scale.

Such developments have led to hopes that democracy is slowly emerging through everyday networks. In contrast, Wang has concluded that 'the Internet is unlikely to offer democratic hope for China' (2009: viii). This is because most users do not take part in political activities, as they participate in government-sponsored activity due to nationalism (ibid. ix). He suggests that Chinese netizens are most likely to protest against foreign forces, in continuity with grassroots nationalism (ibid. 39-40). The regime seems to encourage this channeling of discontent by being relatively tolerant of such protests (ibid. 104). Internet use does not statistically predict protest participation (ibid.112), though this is perhaps to be expected given the correlation of Internet use with high social status.

Western-based websites often act as redistributors of underground dissident material (Abbott, 2001: 103). For instance, the Epoch Times, a Falun Gong-linked newspaper, 
claims to have distributed one of its texts to 2.3 million Chinese users, and drawn 15 million into its campaign to renounce CCP membership (Thornton, 2009: 179). Thornton also suggests that the Epoch Times acts as an amplifier of successful actions (2009: 184). Hence, resistance to the Great Firewall continues to take subversive forms. According to Qiu, '[t]he global networked nature of such oppositional forces is the most fundamental source of frustration' for China (2003: 13). However, activists outside a closed political context have limited leverage over regimes (van Laer and van Aelst, 2009: 246). In related cases within China, students use media such as BBS's to repost controversial material in protest at its censorship (Zhou, 2006: 218). In 2009, Chinese users overran a German website called the 'Berlin Twitter Wall', using it to get around censorship (MacKinnon, 2010: 2). In addition, the fluidity of the Internet has proven useful to both sides, as in the case of the purported resignation of official Meng Weizai, in which resignations and denunciations were exchanged by the two sides (Thornton, 2009: 179-181).

Such contestation on the up-down axis seems particularly risky, however. There is something of an anomaly that mass workers' protests often occur without serious repression, but visible dissidents like Charter 08 can be sentenced to a decade in jail. Much depends on whether a protest can be framed in terms drawing on the regime's own heritage - for instance, strikes against foreign companies (Cunningham and Wasserstrom, 2011: 15-16). The regime also seems harsher on protests which 'have the potential to draw support across generations, across classes, and across the country' than on those focused on local issues (ibid. 18).

Further, Chinese workers continue to be subject to the hegemony of the market and of the state (Blecher 2002: 287). Pun (2005) argues that global capital and market 
mechanisms have inflicted an unprecedented wound on society and that migrant workers have not become a new working class because the state has impeded their emergence: 'Dangongmei, as half peasants and half proletariat, are displaced subjects produced by the hybrid conjugation of state and market machines'. Lee (2007: 71) discusses a range of protests emerging from Chinese workers, differentiating them into a number of categories: Protests against wage and pension arrears; neighbourhood protests over public services; bankruptcy and redundancy protests; protests against corruption and abuse.

Despite the diversity of issues, Lee suggests there is an underlying continuity beneath workers' grievances. 'The common denominator underlying these incidents is a pervasive working class feeling of betrayal by the state and victimization by the market economy' (Lee, 2007: 71). In this sense, these are protests of desperation. Lee looks at how workers frame themselves in protests, including the 'masses' (qunzhong), 'weak and disadvantaged groups' (ruoshi qunti), 'working class' (gongren jieji) and 'citizens' (gongmin). He makes an argument that class consciousness is muted because of problems arising from the identification of working-class power with state socialism. Since new workers (particularly migrants) must confront the domination of the capitalist class while also being excluded from the traditional categories of state socialism, this causes difficulties (Lee, 2007: 195).

Uneven development provides the driving-force behind such unrest. While some are not directly economic, they are generally 'reported as reflecting depressed economic conditions affecting the demonstrators' (Keidel, 2005: 1; c.f. Hung, 2010: 336). Many protests are directly economic, focusing on issues such as pay, layoffs and water rights. Others focus on forced displacement, for instance due to desertification. Even 
ethnic conflicts often have an economic subtext (Keidel, 2005: 2-3). Such problems arise from the shifts entailed by neoliberal reforms, and Chinese peasants and workers 'attribute their difficulties to injustice and government incompetence' (ibid. 6), an analysis brought to crisis-point by corruption and misconduct (ibid. 7-8). The usual modality is for protests to target local injustices and demand central government support to resolve them. According to Keidel's analysis, there are two layers to grievances. Most of their 'basic energy' comes from 'dissatisfaction over the impact of economic reforms', but this is often intensified by 'widespread enterprise and government corruption and malfeasance' (ibid. 1).

The role of the Internet is important in spreading information about such protests and making repression costly, because backfires, thus leading to larger protests. The Weng' an incident discussed by $\mathrm{Li}(2008)$ is a case in which the Internet enabled a rapid spread of information, bypassing regime disinformation and denial. It was reported that 10,000 people attacked official buildings as part of a revolt resulting from a suspicious death blamed on local officials. The spread of images from the revolt required the regime to back down from its initial position of denial and to admit the existence of the revolt. Li goes as far as to argue that the Dengist strategy of using state violence against protests to prevent public demands is no longer effective, as the public has become 'a power beyond law'. With incidents channeling bottled-up anger, and information now more accessible than before due to the Internet, repression is no longer enough ( $\mathrm{Li}, 2008)$. This creates a spectre of the possible spread of revolt: the potential for revolution created by the digital materialisation of protest, theorised as the 'revolutionary virtual' during the Arab Spring uprisings (see Karatzogianni, 2012; 2013). When this risk occurs, the regime no longer resorts mainly to the suppression of dissent, but instead channels unrest against local officials. As a result, in the case of 
Weng' an, 'the primary target of official sanction was not the rioting townspeople but the local officials' ( $\mathrm{Li}, 2008)$.

According to Elizabeth Economy, protests are usually 'local in nature and generally resolved with a combination of payoffs, arrests, and promises of future improvement', occasionally supplemented by 'action against local officials' (Economy, 2004). The regime relies on handling them 'like brush fires', treating each as an isolated case and containing any broader challenge. Economy suggests that this is being undermined by the growing scale of mobilisations, particularly against dam-building, which now cross local and provincial boundaries. Similarly, Lum (2006: 12) suggests that protests have become better organised due to Internet and cellphone technologies. Ecological protests are beginning to link Beijing-based NGOs, which employ virtual communication and lobby for central government support, with militant villagers, who use tactics such as taking officials hostage. In one case, an NGO took villagers to a previous resettlement site to expose inadequate provision. In another, local students acted as bridging connectors to bring local issues onto the Internet. Hence, growing connectedness is undermining the potential for control in the face of sociopolitical uses of the Internet. If business-as-usual proves insufficient, the regime's options seem to be more extreme repression or reform (Economy, 2004).

The modalities of Internet use within this type of activism are mainly sociopolitical. Huang and Yip (2012) examine the Panyu and Xiamen protests and suggest that the Internet had four main uses: as information-disclosure platform, site of discussion, mobilisation structure, and means to find external allies. This typology is typical of sociopolitical uses of the Internet, which focus on mobilisation and network-building. Three sociopolitical uses of the Internet impacting on the offline world are highlighted 
by Yang (2009: 137-138): the instantaneous advertisement of offline protests, the dissemination of online content as posters, and the use of the Internet as an organising space. Similarly, Cai (2008) suggests that the pervasiveness of mobile phones and recording devices makes it more difficult for the state to resort to repression. The pattern can be traced through a number of revolts.

Another example occurred in Guangxi Chuang autonomous region in 2007. Local officials launched a hardline drive to enforce the one-child policy, including forced abortions and home demolitions, sparking local unrest in which official buildings were destroyed (Minzner, 2009: 55). This is another case in which policies were reversed due to unrest, although it is also notable that the harsh crackdown violated central instructions. Minzner argues that local officials were placed in an impossible position between hard targets and restricted methods, which led them to violate the latter (2009: 55-6). Similarly, in 2005, an attack by hired assailants on farmers protesting against a land grab, in which six villagers were killed, was captured on video and publicised on the Internet, leading the regime to fire two local leaders and reverse the land grab (Lum, 2006: 4-5). Even more spectacularly, in 2012 residents of Wukan successfully defeated a land grab by local politicians, seizing control of their village and expelling police. After five days, the government backed down and not only reversed the land grab, but also allowed villagers to elect their own local leaders (The Atlantic, 2012). In 2010, a strike at the Honda Lock car parts factory by undereducated migrant workers revealed strikers to be 'surprisingly tech-savvy'. Accounts were spread online within hours, action coordinated by website, videos of security guard brutality uploaded, and stories of a previous labour victory accessed online. Strikers stopped using the QQ text messaging service after it was infiltrated by guards, but have got around censorship by using code words and alternative networks 
such as VOIP (Barboza and Bradsher, 2010). In another case, Severo et al. (2011) study the Internet spread of a 'Bloody Map' showing patterns of violent evictions in China. A Chinese blogger used forty-six

The relatively positive outcome of some such conflicts is partly due to their recuperability. Because they are focused on the left-right axis and mainly local in scope (even though they function as a synecdoche for wider discontent), they can often be defused through local concessions. Nevertheless, such protests can be seen, as shifting power-relations without rupturing the dominant transcript, a key modality of infrapolitics (Scott, 2012). Protests are usually theorised through O'Brien's (1996) model of 'rightful resistance' using dominant rhetoric and demands for realisation of existing rights and policies. Hung (2010) suggests that the growth of 'mass incidents' in China suggests that people fighting for their rights — known as the wei-quan movement in Chinese - pose a greater threat to the regime than before, and that modern ICTs are part of the reason for this, with 'at least some coordination of action/movement' (Hung, 2010: 331). He suggests that citizens 'are now being awakened and empowered to set their own policy agendas both in cyberspace and physical life' (ibid. 337). However, he also notes that such movements typically do not question regime legitimacy, instead pursuing rights within the dominant frame (ibid. 333). Furthermore, the fact that even western observers cannot establish the sites, causes, casualties or outcomes of most 'mass incidents' points to a continuing information problem.

The impact of the Internet extends to labour movements, despite their arising mainly among the information 'have-less'. As Qiu (2009) observes, knowledge of ICTs is spreading 'to a greater portion of society', leading to 'the formation of grassroots 
urban networks among have-less youth'. This has an amplifying effect on dissent, partially overcoming information problems: 'The problems triggered by for-profit reform force angry youth to roar together — not only in Zhengzhou and Dalian but also online and in the blogosphere - to protest the unfair situations that they are thrown into. This time, their voices are heard' (Qiu, 2009: 140).

Another example discussed by Qiu (2009: 194) about the power of blogs in pre-social media period was the example of Uniden employees 2004 in a Japanese electronics plant in Shenzhen, where the workers used blogs to broadcast the progress of their collective action. Nevertheless, Qiu does not view working-class access to ICTs as constituting a sufficient condition for cultural and political empowerment: 'Given the early formative stage of the technosocial emergence, its still has to involve larger segments of the urban society, including elite members, mass media, and institutionalized forces, especially the state' (Qiu, 2009: 243).

However, a couple of limits have appeared to this type of dissent. There is substantial dissent among rural and labour groups, but their dissent does not overlap substantially with international celebrity dissidents. In general, popular groups are nostalgic for the Maoist period, and hence not necessarily critical of state authoritarianism. However, they tend to be skeptical of neoliberal economic reform and concerned about the problems (such as corruption and instability), which it has brought in its wake (Tang, 2001). Opinion surveys show declining satisfaction with neoliberal reforms, particularly among rural and working-class groups (Tang, 2001: 896, 904). In terms of the Political Compass, this locates them in the top left quadrant. Their grievance with the government runs mainly along the left-right axis, which places them diametrically opposite the celebrity dissidents. In Hu and Zhou's (2002) values mapping, 
Communism shares with post-materialism a spiritual rather than physical needs focus, which places both at odds with individualistic materialism, but differentiates them along an individualism-collectivism axis. Public opinion research in China suggests that there is no significant critical mass for change. Pro-regime attitudes are strongest on issues of social control, with majority support for state authoritarianism, but weaker support for neoliberalism. However, people also report feeling increasingly disempowered, more so than during the Maoist or Dengist eras, as survey results have indicated a declining sense of political efficacy (Tang, 2001).

Another limit is the relative inaccessibility of new technologies. Chinese Internet use has been historically concentrated in the areas (coastal cities) and strata (urban educated middle-class) that benefited from neoliberalism (Abbott, 2001: 106). This stratification has been undermined as usage has spread, but nevertheless, rural and labour strata remain relative 'information have-less'. Today, around 29 percent of the Chinese population has Internet access (Tong and Lei, 2010: i). However, 28.8 percent of users are students, 28.5 percent white-collar and professional workers, and 7.5 percent government staff. Only 2.8 percent are farmers, 4.4 percent documented workers, 2.4 percent migrant workers and 9.8 percent unemployed (Tong and Lei, 2010: 3). Hence, 'those who may benefit the most from counter-hegemonic uses of the Net may be precisely those who have least access to it' (Warf and Grimes, 1997: 270). People in these groups tend to be digital 'have-nots' or 'have-less'. However, Qiu (2009) documents the spread of the Internet to the 'have-less', leading to a workingclass network society used both for self-betterment and labour control. He also suggests that the spread of the Internet today is insufficient for labour empowerment, with Internet use still relying on alliances with other forces (Qiu, 2009: 243). Finally it is important to note that migrants are excluded from protest. A large portion of the 
population are migrants from rural areas who, lacking an urban hukou and corresponding right to live in the cities, are equivalent to undocumented migrants in other areas. Local migrants rarely develop a sense of community in their locality as they lack rights, and they are often blamed for social problems by other residents.

\section{Nationalism, Ethnic, Religious Minorities and the Cybercrime Frame}

Since the Tiananmen Square protests in 1989, the Chinese regime has constructed a new ideological basis in a nationalist narrative aggressively promoted through media, propaganda and education (Zhao, 1998). Key aspects of this narrative include a golden age of national greatness, the 'Century of Humiliation' when greatness was destroyed by imperialists and internal division, and a current re-emergence as a major power. Emergence is articulated somewhat anomalously with economic growth, and seen as dependent on national unity and the prevention of luan. National division and disorder are seen as sources of misery and weakness, usually caused by foreigners (Zheng, 1999: 13-15). Nationalism in China includes elements of pride about economic growth, and a narrative blaming state weakness for earlier humiliations (ibid. 2, 17).

The promotion of nationalism has allowed a relatively free cyberspace to nevertheless remain firmly under regime control. Nationalism is a powerful force in Chinese cyberspace, which includes the aggressive promotion of nationalist discourse throughout the Chinese diaspora, and the crowdsourced reproduction of a narrative of stolen greatness and revival (Wu, 2007). Chinese survey respondents were almost twice as likely to protest over foreign compared to domestic threats (Wang, 2009: 179). Nationalism is often seen as counteracting the tendency for cyberspace and 
indeed protest more broadly to become sites of dissent, with nationalistic netizens and protesters prone to follow the government line even when they have the power to counteract it (ibid.). Indeed, there are recurring rumours that the regime encourages protests targeting foreign countries as a safety valve (Sinclair, 2002: 26). Nationalism is used to encourage passivity and compliance in the face of unpopular reforms (Tang, 2011: 908). Indeed, authoritarian beliefs seem to be actually increasing in response to the apparent success of Chinese development (ibid. 899-900).

Although this is usually seen as reinforcing regime control of the Internet, it also creates spaces for autonomous political discussions through which users 'challenge the state monopoly over domestic nationalist discursive production' (Liu, 2006: 144) and in which the nationalism stoked by the regime spills over outside its control (Hughes, 2002). Wang's research suggests that nationalists are no less likely to protest against the Chinese government than others — the loyalty derived from nationalism seems to be offset by greater online political activity, with the Internet effectively weakening the 'taming effect' of nationalist discourse (Wang, 2009: 189-191). Hence, the Internet can function as a route around ideological blockages. On the whole, however, it seems that the power of nationalism as a form of reactive networkformation allows the emancipatory potential of the Internet to be countered. Networked power emerges, but takes increasingly reactive forms, and is thereby plugged into dominant hierarchical power-apparatuses.

It is this pervasive nationalism, which allows the regime and its supporters to discredit transnational dissidents by portraying them as pro-western and anti-Chinese. In the Global Times, which reflects the Chinese government's views, Shan Renping (16 October 2012) in a surreal twist asks dissidents to overcome their hatred, portraying 
them as irrationally hostile to the regime. He claims that dissidents are 'closing themselves off' to Chinese reform, that 'Chinese are used to Westerners using dissidents', and that prizes for dissidents will fail to undermine relations between China and the west, as he assumes they intend. The logic here is that dissidents are dangerous, because of their potential to use the global mediascape to pressure for reforms.

The major impact of the violence of nationalist discourses has been the repression of ethnic and religious minorities. The most extreme instances of repression have without a doubt occurred in Tibet (Xizang) and East Turkestan (Xinjiang), which are the locations of strong separatist movements. The Chinese media have framed conflicts in Tibet and Xinjiang as ethnic conflicts, and have drawn on a powerful nationalist discourse in countering them. The repression of these protests and revolts has been particularly fierce, with hundreds rounded up and some protesters sentenced to death. Both movements, however, are highly active online, with networked online movements providing a context in which digital nationalisms are sustained in the face of repression.

The Tibetan cause is particularly well-situated. Powers (2004) conducted a web search on Tibet and found that, of the first 230 URLs, all but three were pro-Tibetan, the three being Chinese government sites (p. viii). He observes that 'modern technology, including the advent of affordable desktop publishing and the Internet, allows a people that has lost the war militarily to continue the ideological struggle through the production and reproduction of its version of events' (ibid. 3-4). The Tibetan exile leadership, including the Dalai Lama, use the Internet to disseminate speeches and other material, and have generated worldwide movements, such as the March 10 
commemorative demonstrations (ibid. 143). This strategy is at once sociopolitical, using the Internet mainly to promote a particular view, and ethnoreligious, establishing a conflict frame between two contending accounts. However, the regime has managed to mobilise nationalist counter-protesters to target Tibetan protests abroad, particularly during the Olympic torch relay protests of 2008 (Wang, 2009: 158-159). In Australia, Chinese officials have also been caught sneaking copies of pro-regime works into bookshops (Powers, 2004: vii).

A similar process of survival through the Internet is observed in the persistence of various suppressed spiritual groups such as Falun Gong and qigong groups. Exiled leaders were able to continue to issue directives to followers. Aided by public relations professionals in the west, such sects converted into 'cybersects' able to maintain a network of believers while remaining anonymous (Thornton, 2009: 186). In the case of Falun Gong, Yuezhi Zhao refers to the group's media as 'rhizomatic', 'global', 'multilayered', 'interactive' and increasingly computer-mediated, to the extent that 'the Internet has been instrumental to its more prominent emergence as a transnational global community' (Zhao, 1998 cited in Yang, 2009). Furthermore, they are even able, through an exemplary case of scale-jumping, to organise protests around the world whenever Chinese leaders visit (Tai, 2006: 106). In one case, they were even able to hack into and broadcast on a local radio station in China (Thornton, 2009: 198).

Uighur nationalism in Xinjiang, in common with similar movements worldwide, is a historical construct arising from the educational activities of intellectuals, and took place prior to the rise of the CCP (Schluessel, 2009). Today, the Internet continues such educative activity. Indeed, research suggests that the modern mediascape and 
related consumption are causing Uighur culture to thrive and expand (Erkin, 2009). In this context, Uighur are turning to the Internet to construct narratives of national identity, a phenomenon referred to as cyber-separatism (Gladney, 2004: 229-259). Compared to Tibet, the Uighur cause has proven unattractive in the west due to associations with Islamism, but has powerful resonance in Muslim countries, especially Turkey (Shan and Chen, 11 July 2009: 15-16). Chinese commentators, reluctant to admit a national dimension, chalk the conflicts down to economic inequalities, which persist in spite of affirmative action (Shan and Chen, 11 July 2009: 14). In particular, minorities face disadvantages from lack of contacts in the Handominated national market, and tend to be outside the 'modern' capitalist economy. Local handicrafts and commerce are often decimated by Han-led modern industries, and Uighurs resultantly believe that economic growth benefits only Hans (Shan and Chen, 11 July 2009: 18-19). It has been suggested that the 2009 'Urumqi Riots' in Xinjiang were spread by a 'ripple effect' arising from 'the power of modern communications, such as cell phones and Internet', which explains for instance why an initial fight in Guandong was so quickly translated into conflict in Xinjiang (Shan and Chen, 11 July 2009: 15). Shan and Chen (11 July 2009: 15) suggest that the regime had learnt from the Tibet unrest of 2008, rapidly shutting off cellphones and the Internet, but allowing access by foreign media.

Nationalism also leads to emerging forms of cyberconflict. Nationalist hacktivists react intensely to international conflicts, emerging quickly to coordinate mobilisations. Their 'collectivist tendencies and links to state and corporate establishments' set them aside from western hacktivists (Qiu, 2004: 116), and also clearly mark them as an ethnoreligious cyberconflict group. It takes the form of a recurring 'short-term political spasm', which emerges quickly and aggressively, and disperses quickly under 
state pressure (ibid. 116). In short, China is managing to contain the Internet not only through repression, but also through the constrained flourishing of forms of online self-activity which are marked by mimicry and conformity to the dominant discourse. This model is unstable, requiring both the continuation of Chinese economic growth (the absence of which would cause a legitimacy crisis), and a failure to obtain its goal (the achievement of which would lead to a post-materialist culture and resultant antiauthoritarian movements similar to the 1960s in the North; c.f. Skeldon, 1997: 267).

The successful use of nationalism allows China to rely on hackers to take part in cyberconflict from a pro-government perspective in the event of conflicts with America, Taiwan, Japan and so on. This is considerably different from the basically hostile relationship between western regimes and locally-based hacker communities. China has taken part in crackdowns on piracy and hacking, but in an unenthusiastic way, reflecting the 'killing the chicken to scare the monkeys' principle. In 2010, China responded to international criticism by arresting three hackers, but the move was denounced as 'window dressing' by Canadian cybersecurity expert Ronald J. Deibert (Bradsher, 2010). China also claims to have arrested hundreds of domestic hackers, but focused this crackdown on hacking of Chinese victims (Chao, 2010). There is an exception for anti-regime hacking, which on occasion has even been met with death sentences (Abbott, 2001: 103). On the whole, however, China continues to be a relatively welcoming environment for hacking, and also for commercial cybercrime activities, compared to most western countries. In effect, China seems to be adopting an approach of predominantly seeking to tolerate and recuperate hackers, in contrast to the western response of seeking suppression. This situation potentially serves to locate China at the cutting edge of technological development, as well as 
providing military advantages. It allows China to draw on local hackers to gain advantages in asymmetrical warfare and to carry out inter-state cyberconflict.

It also serves to keep hackers out of the dissident milieu, keeping them focused on ethnoreligious forms of cyberconflict which are useful to the regime. Hacking as a form of asymmetrical warfare is encouraged by Chinese military strategists (Qiao and Wang, 2002; Karatzogianni, 2010: 4). The Chinese government uses hackers to attack the records and accounts of dissidents based outside China (Chase and Mulveron, 2002: 71). For instance, after the 1999 organisation of a demonstration online by Falun Gong, the regime engaged in cyber-attacks against related websites abroad, 'transform[ing] cyberspace into something of an electronic battlefield' (Wacker, 2003: 66). The best-known incident, announced in January 2010, was massive hacking of Google from inside China targeting both dissident gmail accounts and Google's source code (Karatzogianni, 2010: 1). China also appears to be using hackers to 'steal' American software (ibid. 5), aiding technological leapfrogging and breaking superprofit monopolies.

If China has an emerging sector to power its rise to hegemonic status, it may well turn out to be the quasi-black-market mass-production of virtual and real-world goods in an environment of loose enforcement of copyright laws - an environment which is already allowing Chinese companies to leapfrog technological and immaterial gaps and undercut monopolistic western prices with generic versions of consumer goods. Similarly, despite crackdowns, China remains particularly prone to piracy, which was crucial to the transfer of Internet technologies to China in a context of global quasimonopolies (Qiu, 2004: 107-108). China reportedly has one of the highest piracy rates in the world, with a 95 percent piracy rate for movies far exceeding US and EU levels, 
and the US claiming significant trade losses as a result (Eschenfelder et al., 2005). Another example of overlaps between illicit Internet activities and the regime was the story revealed in 2011 that prisoners in labour camps were being forced to play online games as part of the vast 'gold farming' industry run out of China (users play online games in a repetitive way so as to generate in-game currency, which companies sell for real-world money). If China is able to emerge from dependency, it may be that it takes the form of a particularly large, and correspondingly difficult to control 'island in the net', ironically creating a climate for the new forms of virtual productivity which have long been theorised by cyber-libertarians, under the nose of one of the most authoritarian censorship regimes in the world.

\section{References}

Abbott, J.P. (2001), 'Democracy@internet.Asia? The Challenges to the Emancipatory Potential of the Net: lessons from China and Malaysia', Third World Quarterly 22 (1), pp. 99-114.

Amnesty International (2 November 2012) 'China: Amnesty warns of intense crackdown ahead of leadership change'. Online available at: http://www.amnesty.org.uk/news_details.asp?NewsID=20421 (accessed 4 November 2012) 
Appadurai, A. (1990), 'Disjuncture and Difference in the Global Cultural Economy', Theory, Culture, Society 7, pp. 295-310.

Arrighi, G. (2007) Adam Smith in Beijing, London: Verso.

Barbiza, D. (25 October 2012) 'Billions in Hidden Riches for Family of Chinese Leader'. Online available at:

http://www.nytimes.com/2012/10/26/business/global/family-of-wen-jiabao-holds-ahidden-fortune-in-china.html?pagewanted=all

Bandurski, D. (2008) 'China’s Guerilla War for the Web’, Far Eastern Economic Review. Online Available at: http://www.feer.com/essays/2008/august/chinasguerrillawar-for-the-web (accessed 13 September 2010)

Barboza, D. and K. Bradsher (16-06-2010), 'In China, Labor Movement Enabled by Technology', New York Times.

Online Available at:

http://www.nytimes.com/2010/06/17/business/global/17strike.html?pagewanted=all\& $\underline{\mathrm{r}=0}$ (accessed 4 May 2013)

Bennett, I. (2010), 'Media Censorship in China', Washington, DC: Council for Foreign Relations. Online Available at: http://www.cfr.org/china/media-censorshipchina/p11515 (accessed 19 April 2011) 
Blecher, M.J. (2002) 'Hegemony and Workers' Politics in China', The China Quarterly, no. 170, June, pp. 283-303.

Bradsher, K. (February 8 2010), 'China Announces Arrests in Hacking Crackdown', New York Times. Online available at:

http://www.nytimes.com/2010/02/08/world/asia/09hacker.html (accessed 29 April 2013)

Branigan, T. (6 April 2010) 'Cyber-spies based in China target Indian government and Dalai Lama'. The Guardian. Online available at:

http://www.guardian.co.uk/technology/2010/apr/06/cyber-spies-china-target-india (accessed 4 November 2012)

Brenner, N. (1998), 'Global Cities, Glocal States: Global city formation and state territorial restructuring in contemporary Europe', Review of International Political Economy 5:1, pp. 1-37.

Cai, Y (2008) 'Local Governments and the Suppression of Popular Resistance in China', China Quarterly 193, p. 24-42.

Calhoun, C. (1994) Neither God Nor Emperors: Students and the Struggle for Democracy in China, Berkeley: University of California Press. 
Chan, A. (1996) Review of 'Mandate of Heaven: A New Generation of Entrepreneurs, Dissidents, Bohemians and Technocrats Lays Claim to China's Future' by Orville Schell, Pacific Affairs, 69:1, pp. 102-104.

Chase, M. and Mulvenon, J. (2002) You 've Got Dissent! Chinese Dissident Use of the Internet and Beijing's Counterstrategies. California: Rand.

Chen, Shi (1998) 'Leadership Change in Shanghai: Toward the dominance of party technocrats', Asian Survey 38, pp. 671-88.

Clary, G. (25 October 2012) 'Chinese Dissident Ai Weiwei’s Art Becomes His Messenger', CNN. Online Available at:

http://edition.cnn.com/2012/10/13/us/weiwei-exhibit-washington/index.html

Cunningham, M.E. And J.N. Wasserstrom (2011) 'Interpreting Protest in Modern China', Dissent 58: 1, pp. 13-18.

Dann, E.G. and Haddow, N. (2008) 'Just Doing Business or Doing Just Business: Google, Microsoft, Yahoo! and the Business of Censoring China's Internet', Journal of Business Ethics, 79, pp. 219-234.

Dickie, M. (12-11-2007), 'China Traps Online Dissent', Financial Times. Available from: http://www.viet-studies.info/kinhte/China traps online dissent.pdf (accessed 6 May 2013)

Ding, X.L. (2002) 'The challenges of managing a huge society under rapid transformation' in J. Wongand Y. Zheng (eds.) China's post-Jiang Leadership 
Succession: Problems and Perspectives, Singapore: Singapore University Press.

Dowell, W.T. (2006), 'The Internet, Censorship, and China', Georgetown Journal of International Affairs, 7 (2), pp. 111-119.

Economy, E. (2004), 'China's Flood of Protests', Project Syndicate. Online available at: http://www.project-syndicate.org/commentary/china-s-flood-of-protests (accessed 3 May 2013).

Elmhirst, S. (11 October 2012) 'Ai Wei Wei: "If someone is not free, I am not free”. Online Available at: http://www.newstatesman.com/media/media/2012/10/ai-weiweiif-someone-not-free-i-am-not-free (accessed 19 October 2012)

Endeshaw, A. (2004), 'Internet regulation in China: The never-ending cat and mouse game', Information and Communications Technology Law 13 (1), pp. 41-57.

Erkin, A. (2009), 'Locally Modern, Globally Uyghur: Geography, identity and consumer culture in contemporary Xinjiang', Central Asian Survey, 28: 4, pp. 417-28.

Eschenfelder, K.R.; Desai, A.C.; Alderman, I.; Sin, J.; Shen Yi (2005) 'The Limits of DeCSS Posting: A Comparison of Internet Posting of DVD Circumvention Devices in the European Union The People's Republic of China, Hong Kong and Macau', Journal of Information Science, 31: 4, pp. 317-331. 
Falk, B. (2008/9) 'Learning form History: Why We Need Dissent and Dissidents', International Journal, 64:1, Electoral Politics and Policy: Annual John W. Holmes Issue on Canadian Foreign Policy, pp. 243-253.

Feuerberg, G. (6 October 2012) 'US House Members Seek Answers on Transplant Abuse in China', The Epoch Times. Online Available at: ttp://www.theepochtimes.com/n2/world/us-house-members-want-answers-ontransplantation-abuse-in-china-300526.html (accessed 4 November 2012)

Fong, V. (2007) 'SARS, a Shipwreck, a NATO attack, and September 11, 2001:

Global Information flows and Chinese responses to tragic news events', American Ethnologist, 34:3, 521-539.

Frontline (13 December 2005) Interview with Xiao Qiang (Edited transcript), posted 11 April 2006. Online available at:

http://www.pbs.org/wgbh/pages/frontline/tankman/interviews/xiao.html (accessed 19 October 2012)

Fu, Z.J. (2002), 'The state, capital, and urban restructuring in post-reform Shanghai', in J.R. Logan (ed.), The New Chinese City: Globalization and Market Reform, Oxford: Blackwell, pp. 106-20.

Gaubatz, P. (1999), 'China's Urban Transformation: Patterns and processes of morphological change in Beijing, Shanghai and Guangzhou', Urban Studies 36:9, pp. $1495-1521$ 
Ghini, A. (2011) 'Barbarians from without: the role of external forces in Xinjiang Uyghur separatism', PhD Thesis, University of Hull.

Ginkel, J. and Smith, A. (1999) 'So You Say You Want a Revolution: A Game Theoretic Explanation of Revolution in Repressive Regimes', The Journal of Conflict Resolution, 43: 3, pp. 291-316.

Gladney, D.C (2004) Dislocating China: Reflections on Muslims, Minorities and Other Subaltern Subjects, C. Hurst \& Co. Publishers.

Goldkorn, J. (06-01-2013), 'Legal Daily Report on Mass Incidents in China in 2012'. Online available at: http://www.danwei.com/a-report-on-mass-incidents-in-china-in2012/ (accessed 1 May 2013)

Guiheux, G. (2009) (ed.), Social Movements in China and Hong Kong: The Expansion of Protest Space, Amsterdam: Amsterdam University Press, pp. 45-64.

Hardt, M. and Negri, A. (2000) Empire, London and Cambridge, MA: Harvard University Press.

Ho-fung Hung and Iam-ching Ip. (2012) 'Hong Kong’s Democratic Movement and the Making of China's Offshore Civil Society', Asian Survey, 52:3, 504-527. 
Huang, R.G. And N.M. Yip (2012), 'Internet and Activism in Urban China: A case study of protests in Xiamen and Panyu', Journal of Comparative Asian Development 11: 2, pp. 201-23.

Hu, J.J.H. And Zhou H. (2002), 'Information Accessibility, User Sophistication, and Source Credibility: The impact of the Internet on value orientations in mainland China', Journal of Communications and Media Studies 7 (2).

Online available at: http://jcmc.indiana.edu/vol7/issue2/china.html (accessed 2 May 2013)

Hughes, Christopher R. (2002) 'China and the globalization of ICTs: implications for international relations', New Media and Society, 4: 2, pp. 205-224.

Hung, C.F. (2010), 'The Politics of China's Wei-Quan Movement in the Internet Age', International Journal of China Studies 1 (2), pp. 331-49

ITN News. (28 April 2012) 'Escaped Chinese activist Chen Guangcheng releases online video'. YouTube Video. Online Available at: http://www.youtube.com/watch?v=Qe8sRywbjbs

Jacobs, A. (1 November 2012a) 'From Toys to TV News, Jittery Beijing Clamps Down', The New York Times. Online Available at: http://www.nytimes.com/2012/11/02/world/asia/chinas-heavy-hand-smooths-way-toparty-congress.html (accessed 4 November 2012) 
Jacobs, A. (1 November 2012b) 'Chinese Café Owner Given 8-Year Sentence for Posting Online Messages', The New York Times. Online Available at: http://www.nytimes.com/2012/11/02/world/asia/chinese-cafe-owner-given-8-yearsentence-over-online-messages.html?ref=asia (accessed 4 November 2012)

Jessop, B. and N.L. Sum (2000), 'An entrepreneurial city in action: Hong Kong's emerging strategies in and for (inter)urban competition', Urban Studies 37:12, pp. $2287-2313$

Johnson, I. (2 November 2012) 'China’s Emigrant Attrition', International Herald Tribune.

Kalathil, S. and Boas, T.C. (2003) Open Networks, Closed Regimes: The Impact of the Internet on Authoritarian Rule, Washington: Carnegie Endowment for International Peace.

Karatzogianni, A. (2013) 'A Cyberconflict Analysis of the 2011 Arab Spring' in Youngs, G. (ed.) Digital World: Connectivity, Creativity and Rights, London and New York Routledge.

Karatzogianni, A. (2012a) 'WikiLeaks Affect: Ideology, Conflict and the Revolutionary Virtual' in A. Karatzogianni and A. Kunstman (eds.) Digital Cultures and the Politics of Emotion: Feelings, Affect and Technological Change, Basingstoke: Palgrave MacMillan.

Karatzogianni, A. (2012b) 'Blame it on the Russians: Tracking the Portrayal of 
Russian Hackers During Cyber Conflict Incidents' in A. Karatzogianni (ed.) Violence and War in the Media: Five Disciplinary Lenses, London and New York: Routledge.

Karatzogianni, A. (10 March 2010) 'The Thorny Triangle: Cyber Conflict, Business and the Sino-American Relationship in the World-System', e-International Relations. Online available at: http://www.e-ir.info/?p=3420

Karatzogianni, A. (ed.) (2009) Cyber Conflict and Global Politics, Routledge: London and New York.

Karatzogianni, A. (2006) The Politics of Cyberconflict, Routledge Research on Internet and Society, Routledge: London and New York.

Karatzogianni, A. and Robinson, A. (2010) Power, Resistance and Conflict in the Contemporary World: Social Movements, Networks and Hierarchies, Routledge: London and New York.

Karatzogianni, A. and Schandorf, M (20 October 2012). 'Agency, Resistance, and Orders of Dissent against the Capitalist Code', presented at the Association of Internet Researchers Conference 13.0, Salford University.

Keidel, A. (26 May 2005) 'The Economic Basis for Social Unrest in China'. Online Available at: http://www.carnegieendowment.org/files/Keidel Social Unrest.pdf. (accessed 2 July 2013) 
Kelliher, D. (1993) 'Keeping Democracy Safe from the Masses: Intellectuals and Elitism in the Chinese Protest Movement', Comparative Politics, 25:4, pp. 379-396.

Kluver R. (2005) 'The Architecture of Control: A Chinese Strategy for EGovernance', Journal of Public Policy, 25:1, pp. 75-97.

Kuah-Pearce, K.E. (2009), 'Defining Hong Kong as an Emerging Protest Space: The Anti-Globalization Movement', in G. Guiheux (ed.), Social Movements in China and Hong Kong: The Expansion of Protest Space, Amsterdam: Amsterdam University Press, pp. 91-116.

Kurlantzick, J. (2003) 'The Dragon Still Has Teeth: How the West Winks at Chinese Repression', World Policy Journal, 20:1, pp. 49-58.

Lamborn, K. 'Chinese dissident's remake of Gangham Style is banned'. ITN News. Video. Online Available at: http://www.itn.co.uk/World/59790/chinese-dissidentsremake-of-gangnam-style-is-banned (accessed 4 November 2012)

Larson, K. (29 October 2012) 'Protests in China Get a Boost from Social Media', Bloomberg Business Week. Online Available at:

http://www.businessweek.com/articles/2012-10-29/protests-in-china-get-a-boost-from$\underline{\text { social-media }}$ (accessed 4 November 2012)

Lee, C. K. (2007) Against the Law: Labor Protests in China's Rustbelt and Sunbelt, Berkeley: University of California Press. 
Lee, P. (31 October 2012) 'Insider Training, Chinese Style', Asia Times. Online Available at: http://www.atimes.com/atimes/China/NJ31Ad02.html (accessed 4 November 2012)

Lewis, H. (18 October 2012) 'Taking on the "Great Firewall of China”, New Statesman. Online Available at: http://www.newstatesman.com/staggers/2012/10/taking-great-firewall-china (accessed 2 November 2012)

Li, D.T. (July 30 2008) 'The Weng'an Model: China's Fix-it Governance', Open Democracy.

Available from: http://www.opendemocracy.net/article/the-wengan-model-china-s-fixit-governance (accessed 6 April 2011)

Li, L.J. (2006), 'Driven to Protest: China's Rural Unrest', Current History 105 (Sept), pp. 250-254.

Liu, S.D. (2006), 'China's Popular Nationalism on the Internet: Report on the 2005 anti-Japan network struggles', Inter-Asia Cultural Studies 7 (1), pp. 144-55.

Lin, G.C.S. (2002), 'Region-based urbanization in post-reform China: Spatial restructuring in the Pearl River Delta', in J.R. Logan (ed.), The New Chinese City: Globalization and Market Reform, Oxford: Blackwell, pp. 245-57. 
Liu, J.F. (2011), 'Picturing a Green Virtual Public Space for Social Change: A study of Internet activism and web-based environmental collective actions in China', Chinese Journal of Communication 4: 2, pp. 137-66.

Lum, T. (2006), 'Social Unrest in China', Congressional Research Service Reports and Issue Briefs. Online available at:

$\underline{\text { http://digitalcommons.ilr.cornell.edu/cgi/viewcontent.cgi? } \operatorname{article}=1018 \& \text { context }=\mathrm{crs} \& \mathrm{~s}}$ $\underline{\mathrm{ei}-}$ $\underline{\text { redir}}=1 \&$ referer=http $\% 3 \mathrm{~A} \% 2 \mathrm{~F} \% 2 \mathrm{Fscholar}$. google.co.uk\%2Fscholar\%3Fstart $\% 3 \mathrm{D} 30 \%$ 26q\%3Dchina\%2Bprotest $\% 26 \mathrm{hl} \% 3 \mathrm{Den} \% 26$ as $\mathrm{sdt} \% 3 \mathrm{D} 0 \% 2 \mathrm{C} 5 \#$ search $=\% 22 \mathrm{china} \% 20$ protest $\% 22$

(accessed 3 May 2013)

Ma, N. (2009), 'Social Movements and State-Society Relationship in Hong Kong', in G. Guiheux (ed.), Social Movements in China and Hong Kong: The Expansion of Protest Space, Amsterdam: Amsterdam University Press, pp. 45-64.

MacKinnon, R. (2010), 'Networked Authoritarianism in China and Beyond: Implications for global Internet freedom'. Presented at Stanford University, Conference on Liberation Technology in Authoritarian Regimes, October 11-12. Available from: http://iis-db.stanford.edu/evnts/6349/MacKinnon Libtech.pdf (accessed 4 May 2013)

Mu, Y. and Thomson, M. (1989) Crisis at Tiananmen: Reform and Reality in Modern China, San Francisco: China Books and Periodicals. 
Mengyu Dong. (3 November 2012) 'Looking For Song Ze' China Digital Times http://chinadigitaltimes.net/2012/11/looking-for-song-ze/ (accessed 4 November 2012)

Minzner, C.F. (2009), 'Riots and Cover-Ups: Counterproductive Control of Local Agents in China', University of Pennsylvania Journal of International Law 31: 1, pp. 53-123.

Mulvenon, J. and Yang, R. (1999) The People's Liberation Army in the Information Age. California: Rand.

O’Brien, K.J. (ed.) (2008) Popular Protest in China, Harvard, Harvard University Press.

O'Brien, K.J. and Li, L. (2006) Rightful Resistance in Rural China, New York and Cambridge: Cambridge University Press.

Powers, J. (2004), History as Propaganda: Tibetan Exiles versus the People's Republic of China, Oxford: Oxford University Press.

Pun, N. (2005) Made in China: Women Factory Workers in a Global Workplace, Durham and London: Duke University Press.

Pye, L.W. (2001) Review Essay 'Appealing the Tiananmen Verdict: New Documents from China's Highest Leaders', Foreign Affairs, 80: 2, pp. 148-154.

Pye, L.W. (1990) 'Tiananmen and Chinese Political Culture: The Escalation of Confrontation from Moralizing to Revenge', Asian Survey, 30:4, pp. 331-347. 
Qiu, J. L. (2009) Working-Class Network Society: Communication Technology and the Information have-less in Urban China. Cambridge, Massachusetts and London: The MIT Press.

Qiu, J.L. (2004) 'The Internet in China: Technologies of Freedom in a Statist Society' in M. Castells (ed.) Network Society: A Cross-Cultural Perspective, London: Edward Elgar.

Qiao, L.A. and X.S. Wang (2002), Unrestricted Warfare, Panama City: Pan-American. Radio Free Asia. (3 November 2012) 'Court Rejects Chen Lawsuit', Online available at: http://www.rfa.org/english/news/china/lawsuit-11022012103759.html (accessed 4 November 2012)

Ramzy, A. (7 October 2012) 'The Artist Who Can't Leave China: An Interview with Ai Weiwei', Online. Available at: http://world.time.com/2012/10/07/the-artist-whocant-leave-china-an-interview-with-ai-weiwei/ (accessed 4 November 2012)

Rawnsley, G. D. (2007) 'Virtual China: The Internet as Threat or Opportunity?, St. Antony's International Review, 3:1, pp. 42-57.

Rawnsley, G. D. 'The Media, Internet and Governance in China', China Discussion Paper \#12 (September 2006), China Policy Institute, University of Nottingham (at: http://www.nottingham.ac.uk/china-policyinstitute/publications/discussionpapers.php) 
Rawnsley, G.D. and Rawnsley, M.Y.T. (2003) Political Communications in Greater China, RoutledgeCurzon.

Rawnsley, M.Y.T (2012) ‘The Media in Democratic Taiwan’ D. Blundell (ed.) Taiwan Since Martial Law: Society, Culture, Politics, Economy. University of California: Berkeley \& National Taiwan University Press.

Rimmer, P.J (2002), 'Overview: restructuring Chinese space in the new millennium', Asia Pacific Viewpoint 43, pp. 1-8.

Reese, S. and Dai, J. (2009) 'Citizen journalism in the global news arena: China's new media critics' in S. Allan and E. Thorsen (eds.) Citizen journalism: Global perspectives, New York: Peter Lang.

Scott, J.C. (2012) 'Infrapolitics and Mobilizations: A Response by James C. Scott'. Online Available at: http://www.cairn.info/resume.php?ID ARTICLE=RFEA 1310112

Severo, M., Giraud, T and Douay, N. (2011), 'Citizen Protest in Online Networks: The case of China's bloody map', paper presented to the $7^{\text {th }}$ Social Network Conference, London, UK.

Online available at: http://hal.archivesouvertes.fr/docs/00/67/55/17/PDF/BloodyMap Severo inviato.pdf (accessed 4 May 2013) 
Shan, W. and Chen, G. 'The Urumqui Riots and China's Ethnic Policy in Xinjiang', Online available at: http://www.eai.nus.edu.sg/Vol1No3_ShanweiChenGang.pdf

Shi, Y.L. and C. Hamnett (2002), 'The potential and prospect for global cities in China: in the context of the world system', Geoforum 33, pp. 121-35.

Shu-Yun Ma. (1993) 'The Exit, Voice, and Struggle to Return of Chinese Political Exiles', Pacific Affairs, 66:3, pp. 368-385.

Sikkink, K. (1993) 'Human Rights, Principled Issue-Networks, and Sovereignty in Latin America', International Organization, 47: 3, pp. 411-441.

Shan, Renping. (16 October 2012) 'Exiled Dissidents Should Leave Hatred Behind', Global Times. Online Available at: http://www.globaltimes.cn/content/738704.shtml (accessed 4 November 2012)

Shao, Jiang. (1 November 2012) 'Weighty Times, Aggressive Measures: China Must End Heightened Crackdown Ahead of Party Congress', Amnesty International UK/Blogs, Online Available at: http://www2.amnesty.org.uk/blogs/countdownchina/weighty-times-aggressive-measures-china-must-end-heightened-crackdownahead (accessed 4 November 2012)

Schluessel, E.T. (2009), 'History, Identity and Mother-Tongue Education in Xinjiang', Central Asian Survey, 28: 4, pp. 383-402. 
Sinclair, G. (2002), 'The Internet in China: Information Revolution or Authoritarian Solution?', Dissertation.

Available from: http://www.geocities.ws/gelaige79/intchin.pdf (accessed 4 may 2013)

Sui-Lee Wee. (6 November 2012) ‘Chinese Women’s rights activist sent to labour camp again', Reuters. Online available at: http://uk.reuters.com/article/2012/11/06/ukchina-labour-idUKBRE8A50DG20121106 (accessed 7 November 2012)

Sun, W. (2010) 'Scaling Chinese Media: A Geographic Turn to Future Research', International Journal of Communication 4, pp. 537-543.

Sunstein, C. (2003) Why Societies Need Dissent, Cambridge: Harvard University Press.

Tai, Z. (2006) The Internet in China: Cyberspace and Civil Society, New York: Routledge.

Wenfang Tang, (2001) 'Political and Social Trends in the Post-Deng Urban China: Crisis or Stability?', The China Quarterly. 168 , pp. 890-909

Tatlow, D.K. (17 October 2012a) 'Dissident Writer Calls for the Breakup of the Chinese Empire'. IHT Rendezvous. Online Available at: http://rendezvous.blogs.nytimes.com/2012/10/17/dissident-writer-calls-for-thebreakup-of-the-chinese-empire/ (accessed 4 November 2012) 
Tatlow, D.K. (17 October 2012b) 'In 3 Awards, 3 Ways of Seeing China', The New York Times. Online Available at:

http://www.nytimes.com/2012/10/18/world/asia/18iht-letter18.html (accessed 4 November 2012)

Taubman, G. (1998), 'A Not-So World Wide Web: The Internet, China, and the Challenges to Nondemocratic Rule', Political Communication 15: 2, pp. 255-72.

Taylor, P.J. (2000), 'World Cities and Territorial States under Conditions of Contemporary Globalization II: Looking forward, looking ahead', Geoforum 52, pp. $157-62$.

Taylor, P.J., P. Ni, B. Derudder, M. Hoyler, J. Huang, F. L, K. Pain, F. Witlox, X. Yang, D. Bassens and W. Shen (2009), 'The way we were: command-and-control centres in the global space-economy on the eve of the 2008 geo-economic transition', Environment and Planning A 41, pp. 7-12.

The Atlantic (Feb 17, 2012), 'Rising Protests in China'.

Available from: http://www.theatlantic.com/infocus/2012/02/rising-protests-inchina/100247/ (accessed 1 May 2013)

The China Post (15 October 2012) 'China Writers Laud Mo for release Call'. Online available at: http://www.chinapost.com.tw/art/books/2012/10/15/357664/Chinawriters.htm (accessed 4 November 2012) 
The Economic Times (ET Bureau). (3 November 2012) Why China's stabilityobsessed rulers are taking no chances, avian or otherwise'. Online available at: http://articles.economictimes.indiatimes.com/2012-11-03/news/34892120_1_pigeonstaxi-drivers-hu-jia (accessed 4 November 2012)

Thornton, P.M. (2009), 'Manufacturing Dissent in Transnational China: Boomerand, Backfire or Spectacle?', in K. O'Brien (ed.), Popular Protest in China, Harvard: Harvard University Press.

Tong Y.Q. And Lei S.H. (2010), 'Creating Public Opinion Pressure in China: Largescale Internet Protest', EIA Background Brief No. 534.

Online available at: http://www.eai.nus.edu.sg/BB534.pdf (accessed 2 May 2013)

Tuinstra, F. (2009), 'Internet Censorship: The Myth, Oft Told, and the Reality', Nieman Reports. Online available at:

http://www.nieman.harvard.edu/reports/article/101905/Internet-Censorship-The-MythOft-Told-and-the-Reality.aspx (accessed 4 May 2013)

Van Laer, J. and P. van Aelst (2009), 'Cyber-Protest and Civil Society: the Internet and Action Repertoires in Social Movements', in Y. Jewkes and M. Yar, Handbook on Internet Crime, Willan, pp. 230-54. 
Wacker, G. (2003), 'The Internet and Censorship in China', in C.R. Hughes and G. Wacker, China and the Internet: Politics of the Digital Leap Forward, London and New York: Routledge.

Walton, G. (2001) China's Golden Shield: Corporations and the Development of Surveillance Technology in the People's Republic of China, International Centre for Human Rights and Democratic Development.

Wang, X.R. (2009), Behind the Great Firewall: The Internet and Democratization in China, PhD Dissertation, University of Michigan.

Online available at:

http://141.213.232.243/bitstream/handle/2027.42/64681/wangx 1.pdf;jsessionid=5E15 7B3861C0405E66420FBB7B68A65F?sequence $=1$

(accessed 4 May 2013)

Warf, B. and Grimes, J. (1997) 'Counterhegemonic discourses and the internet'. The Geographical Review, 87: 2, pp. 259-274.

Wei, Y.D. And C.K. Leung (2005), 'Development zones, foreign investment, and global city formation in Shanghai', Growth and Change, 36: 1, pp. 16-40.

Wolpe, H. (1972), 'Capitalism and Cheap Labour-Power in South Africa: From Segregation to Apartheid', Economy and Society 1: 4, pp. 425-56.

Wu, F. L. (2000). 'The global and local dimensions of place-making: remaking Shanghai as a world city', Urban Studies, 
37: 8, pp. $1359-1377$.

Wu, X. (2007) Chinese Cybernationalism: Evolution, Characteristics, and Implications, Langham, Md: Lexington Books.

Yang, G.B. (2009), 'Contention in Cyberspace', in K.J. O'Brien (ed.), Popular Protest in China, Cambridge, MA: Harvard University Press, pp. 126-43.

Yang, G. (2009) The Power of the Internet in China: Citizen Activism Online. New York: Columbia University Press.

Yang, G. (2005) 'Environmental NGOs and Institutional Dynamics in China', The China Quarterly, 181, 2005: 46-66.

Yang, G.B. (2003), 'The Co-Evolution of the Internet and Civil Society in China', Asian Survey 43: 3, pp. 405-22.

Yu, Verna. (16 January 2010) 'Big Brother' a Constant, Chilling Presence for Bloggers and Activists', South China Morning Post.

Yusuf, S. and Wu, W. (2002) 'Pathways to a World City: Shanghai Rising in an Era of Globalisation, Urban Studies, 39: 7, 1213-1240.

Zhao, K. (2011), 'Boundary-Spanning Contention: The Panyu Anti-Pollution Protest in Guangdong, China', Stanford Journal of East Asian Affairs 11 (1).

Online available at: http://www.stanford.edu/group/sjeaa/journal111/China2.pdf 
(accessed 6 May 2013)

Zhao, S.S. (1998), 'A State-Led Nationalism: The patriotic education campaign in post-Tiananmen China', Communist and Post-Communist Studies 31: 3, pp. 287-302.

Zhao, Y. (1998) Media, Market and Democracy in China, Urbana, University of Illinois Press.

Zheng, Y. (2008) Technological Empowerment: The Internet, State, and Society in China, Stanford. Ca: Stanford University press.

Zheng, Y. (1999), Discovering Chinese Nationalism in China: Modernization, Identity, and International Relations, Cambridge: Cambridge University Press.

Zhou Q. (n.d.), 'The emerging environmental protest in China and its impacts on the growth of Chinese civil society'.

Online available at: http://www.inter-disciplinary.net/wpcontent/uploads/2011/06/zhouqianepaper.pdf (accessed 4 May 2013)

Zhou, Y. (2006) Historicizing Online Politics: Telegraphy, The Internet, and Political Participation in China, Stanford, Ca: Stanford University Press.

Zhou, Y. (2005) 'Living on the Cyber Border: Minjian Political Writers in Chinese Cyberspace', Current Anthropology, 46:5, 779-803. 
Zhou, K. (28 August 2008) ‘China’s Grassroots Movement Toward Greater Freedom’, Economic Reform Freedom Service, Washington: Centre for international Private Enterprise.

Zhou, M. and J.R. Logan (2002), 'Market transition and the commodification of housing in urban China', in J.R. Logan (ed.), The New Chinese City: Globalization and Market Reform, Oxford: Blackwell, pp. 137-52.

Zittrain, J. and B. Edelman (2003), 'Empirical Analysis of Internet Filtering in China', Cambridge, MA: Harvard Law School.

Zittrain, J. and J. Palfrey (2010), 'Internet Filtering: The Politics and Mechanisms of Control', in R. Deibert, J. Palfrey, R. Rohozinski and J. Zittrain (eds), Access Controlled: The Shaping of Power, Rights and Rule in Cyberspace, Cambridge, MA: MIT Press, pp. 15-35.

Zweig, D. (2002) Internationalizing China: Domestic Interests and Global Linkages, Ithaca, NY: Cornell University Press. 